\title{
Ellipsis
}

\section{A Painful Turning: American Confessional Poets on Human Suffering Abroad}

Christine Baniewicz

The University of New Orleans

Follow this and additional works at: https://scholarworks.uno.edu/ellipsis

\section{Recommended Citation}

Baniewicz, Christine (2016) "A Painful Turning: American Confessional Poets on Human Suffering Abroad," Ellipsis: Vol. 43 , Article 5.

DOI: https://doi.org/10.46428/ejail.43.05

Available at: https://scholarworks.uno.edu/ellipsis/vol43/iss1/5

This Literary Criticism is brought to you for free and open access by the Department of English and Foreign Languages at ScholarWorks@UNO. It has been accepted for inclusion in Ellipsis by an authorized editor of ScholarWorks@UNO.For more information, please contact scholarworks@uno.edu. 


\title{
A Painful Turning: American Confessional Poets on Human Suffering Abroad
}

\author{
Christine Baniewicz \\ The Malcolm Magaw Prize for Best Graduate Student Essay \\ ...burned human flesh \\ is smelling in Viet Nam as I write. \\ Yes, this is the knowledge that jostles for space \\ in our bodies along with all we \\ go on knowing of joy, of love... \\ - Denise Levertov, "Life at War," The Sorrow Dance
}

In her essay, "Tourism and promised lands," poet Adrienne Rich warns against writing what she terms "poetry of vacation rather than vocation," what we today would probably call travel writing. "Many of the poems in my second book," she recalls, "were poems of such tourism. It was a difficult, conflicted time in my own life, from which I gladly fled into poems about English or Italian landscape and architecture" (228-231). To her mind, such poems are "a trap for poets, especially poets of North America who may elect to be escapist, breezy, about our empire" (228).

But what of the North American poet who, in the course of her life or work in activism, encounters human suffering outside of our empire? To write on this topic - particularly in the confessional mode - a poet risks a wide variety of traps. After all, to write as Denise Levertov did about Vietnam; or to tackle, as Sharon Olds did, state-sanctioned violence in Chile; or to speak, as Carolyn Forché did in her collection The Country Between Us, on the atrocities in El Salvador - to do such work without wandering into the territory of the sensational or exploitative, without rendering the subjects of violence as flat, exotic, twodimensional victims ("abstract figures on a simplified ground" [Rich What 228]), without obscuring one's own post-colonial complicity in the violence, without penning hysterical arias of guilt and helplessness, without writing poems "in the genre of revolutionary tourism" (qtd. in Valis 123) —-this is a difficult undertaking.

And yet, as Rich muses, "who is to dictate what may be written about and how?" (What 229) Moreover, according to Levertov, 
...good poets write bad political poems only if they let themselves write deliberate, opinionated rhetoric, misusing their art as propaganda... A poet driven to speak to himself, to maintain a dialogue with himself, concerning politics, can expect to write as well upon that theme as upon any other. (115)

Taken in this light, the confessional mode may be understood to have an edge on other forms when it comes to writing about politics, as it's hard to imagine a poetic mode better suited for maintaining a dialogue with oneself. Instead of engaging directly with the political ideology or military regime to which she objects, the confessional poet can take a more intimate tack, allowing the reader access to her own emotional and psychological turmoil as she encounters the brutal reality of suffering in a foreign land and struggles to assimilate it. This encounter with new knowledge, in the most developed poems, forces the poet to learn something - about herself and the nature of death, life and human suffering. These poems aim, unlike more traditional, didactic political poetry, to move the reader to sympathize with both the victims of violence abroad and the poet herself. By focusing on the American poet's response, the writer models for the Western reader a way in which he or she might respond to the reality of human suffering abroad.

The effectiveness of such poems, I posit, relies upon the poet's ability to do the following three things: make clear the distinction between her own psychological suffering and the suffering of those affected by violence abroad, even as she explores similarities and parallels; portray foreign subjects with dignity, respect and particularity by avoiding tropes; and wherever possible confront, interrogate and/or recast the feelings of helplessness and self-pity that work to obscure her own grief and less-than-altruistic motivations for engaging with the foreign conflict in the first place.

In the interest of substantiating this claim, and concretizing the examples I list above, I turn first to the poetry of Adrienne Rich.

Of primary concern to the North American confessional poet who represents foreign subjects - particularly, those from "so-called Third World" countries $^{1}$ (Said 46) - is doing so with sensitivity to the fact that, as Edward Said notes in Orientalism, "a certain freedom of intercourse was always the Westerner's privilege; because his was the stronger culture, he could penetrate, he could wrestle with, he could give shape and meaning to the great Asiastic mystery." Said speaks of the "constricted vocabulary of such a privilege, and the comparative limitations of such a vision" (Said 44).

How a North American poet chooses to work within these limitations has great bearing on how effective her work will be at moving a reader to sympathize both with the speaker of the poem and the subjects she represents. In her poem "Hunger" from the collection Dream of a Common Language, for example, Rich acknowledges the limits of her "Western vision" directly in the text as she writes about hunger in Africa:

...I know I'm partly somewhere else-

huts strung across a drought-stretched land

not mine, dried breasts, mine and not mine, a mother 
watching my children shrink with hunger.

I live in my Western skin,

my Western vision, torn

and flung to what I can't control or even fathom. (12)

Rather than assume an authoritative posture towards the subject, Rich takes a more candid approach by confessing her inability to "even fathom" the suffering about which she writes. This candor frees her to take on the challenge of imagining it without falling into the trap - particular to the Western poet in the post-colonial age — of "attempting to represent herself as anything more than an outsider" (Valis 121). Thus, when we encounter Rich's vision of hunger in Africa - "in Chad, in Niger, in the Upper Volta—," “...our brains blunted by malnutrition,/ yet sharpened by the passion for survival,/our powers expended daily on the struggle/ to hand a kind of life on to our children" (13) - we know she is speaking to us as a Western woman, and that her description is not meant to be taken as an authoritative view on life in Africa, but rather, as an attempt to "mobilize empathy, compassion, the imaginative capacity for suffering with" the people who live there (Des Pres 363).

Moreover, Rich takes care in the early lines of the poem to mark a distinction between her own suffering - her "Western skin and vision," her own sense of feeling "torn" - and the suffering of the foreign subjects - their huts "not mine," she writes. This distinction, once drawn, however, is quickly troubled as the poem develops, exploring similarities and parallels between the suffering of Western women and the suffering of African women (mothers, specifically).

They can rule the world while they can persuade us that our pain belongs in some order.

Is death by famine worse than death by suicide, than a life of famine and suicide, if a black lesbian dies, if a white prostitute dies, if a woman genius starves herself to feed others, self-hatred battening on her body? (12)

Rich suggests in these lines that, while distinct, the pain of women in both continents is similar; related, even ("yes, that male god that acts on us and on our children" [emphasis mine]) (13). Thus, as Des Pres notes, "Rich returns repeatedly to the image of mothers and children; as a woman and a mother, she trusts maternal anger to guide her art" (366). Rich, while not an African mother, has raised children, and can speak with authority on that subject. Much of this poem's effectiveness at inspiring sympathy for starving women and children in Africa springs from the poet's choice to anchor her empathic vision of their suffering on a shared experience: mothering.

But what of all those "huts," those "dried breasts," images that smack of generalized African tropes? According to Said, the common tropes associated with depictions of third-world countries tend to characterize those countries and the people who live there in terms of their "backwardness, degeneracy, and inequality with the West." (207) Additionally, he writes, ...we need not look for correspondence between the language used to depict the Orient and the Orient itself, not so much because the 
language is inaccurate but because it is not even trying to be accurate. What it is trying to do...is at one and the same time to characterize the Orient as alien and to incorporate it schematically on a theatrical stage whose audience, manager, and actors are for Europe, and only for Europe. (71-72)

Insofar as Rich has written the poem in English for a primarily Western readership, and huts are an "alien" form of housing in North America, one could argue that the text is problematic from a post-colonial standpoint. In his article "Postcolonial Africa? Problems of Theory," Peter Hitchcock considers an Algerian book written in French, arguing that the very language of the text is significant; that although the content of a piece may "defamiliarize and denature" the "colonial impulse in history...the fact remains that the circulation of this view is afforded by the brute reality of French as an international language of exchange." He goes on to note, however, that "the power and prescience of [the author's] artistic vision are not nullified by this reality," only that it warrants attention from the standpoint of post-colonial scholarship. (242)

What's more, despite Rich's invocation of a familiar trope - the African huts - she by and large avoids depicting Africa as "diametrically inferior to a European equivalent" (Said 72) by repeatedly implicating herself ("my guilt at least is open, / I stand convicted by all my convictions"), including herself in the descriptions she provides - "dried breasts, mine and not mine," "our brains blunted by malnutrition...our powers expended daily on the struggle" (emphasis mine) (13). Whereas problematic post-colonial depictions of "the Other" imply "Western superiority" (Said 42), Rich endeavors again and again in "Hunger" to dismantle any sense of quantitative differentiation between the suffering of women on one continent or the other. In this way, Rich manages for the most part to sidestep the tropes (or, in the case of the dried breasts, include herself under their wide, general net), invoking instead a variety of particular, dignifying images of women. She references a series of wrenching images of women suffering by visual artist Kathe Kollwitz ("leafing through Kollwitz's women,/ huddling the stricken children into their stricken arms"), as well as the final image: "on the trampled newsprint, / a woman shields a dead child from the camera./ The passion to be inscribes her body."

In this image, the foreign subject is not "inferior;" is not rendered to appear "backwards" or "degenerate," but rather powerful, strong, fierce with desire. This is not a passive, hut-dwelling, dry-breasted victim of circumstance but an actor, an agent in her own life - note the active verb, shield-however fraught her life may be with pain and suffering.

It's easy to imagine "Hunger" coming under attack by critics like Eliot Weinberger, who would likely accuse Rich — as he did Forché — of attempting to coerce readers into believing that the suffering of Africa is the poet's own suffering (Valis 123). Has Rich's enduring feminism overstepped its bounds here, as she lumps together, primarily by use of the pronoun "our," the suffering of the African female Other with all of women's suffering? Or is it the very fact of her feminist ideology that allows her to speak with some authority on the topic? After all, as Hitchcock notes, "masculinism does not disappear with the end of 
colonialism: It can embrace both the tenets of anti colonial nationalism and the otherwise progressive intentions of postcolonial statehood." He cites the "centrality of feminist questions for contemporary postcoloniality," (240) namely: "who speaks for whom? Who can speak? Who gets silenced in the act of someone else's speaking?" (237) The intersectionality of these two theoretical standpoints is evident in "Hunger," as Rich seems to blame "that male god" for the victimization and hunger of all women everywhere, as if "victimization were the basis of tribal union," suggesting that "the solidarity of political victims exists de facto." (Des Pres 367)

Effective confessional poetry about politics almost always closes with an image or statement reflecting where it is that the poet locates value, particularly after her emotional equilibrium has been so profoundly disturbed by the violent reality of suffering she's considered over the course of the poem. It is as if, after being shaken to the core, the poet spares a final moment to reflect on what that core is. In the case of "Hunger," Rich describes her own face reflected in a subway window and the aforementioned woman in newsprint with her dead child, and writes in closing, "Until we find each other, we are alone" (14). Rather than rehearse the familiar tropes of us-and-them, Rich urges us to reach in solidarity across "the black mirror" (14) towards other women, women suffering both here in North America and elsewhere in the world. It's within this imagined moment of connection with one another that Rich locates meaning.

In writing confessional poetry on topics of human suffering abroad-especially as "citizens of the country which, in its ruthless imperialism...its military bases... and the tentacles of its giant corporations, is everywhere the prime force of antilife and oppression" (Levertov 124) — it seems reasonable to expect that a poet's guilt and shame might obscure the poem's subject; or, in their excess, become the poem's subject.

But "self-reproach," according to Levertov, "can be a form of selfindulgence" (145). Nowhere is such indulgent shame so refreshingly absent than in the poetry of Levertov and Rich's younger contemporary Sharon Olds. Throughout her collection The Dead and The Living, Olds tackles subjects both "public" and "private," and whether writing about her alcoholic father, her sixyear-old son's erection, or state-sanctioned torture in the violent, U.S.-backed Chilean regime, Olds speaks unabashedly.

Such is the case in her poem, "Things That Are Worse Than Death." Rhythmically driving, emphatic and disturbing, the poem offers an extended internal look at the poet's attempt to assimilate a story of violent torture perpetrated against a mother and son in Chile.

You tell how the guards tortured the woman, the man, the child, in front of each other, "as they like to do." Things that are worse than death. I can see myself taking my son's ash-blond hair in my fingers, tilting back his head before he knows what is happening, slitting his throat, slitting my own throat 
to save us that. (13)

Like Rich, Olds chooses to speak in these lines as a mother, to imaginatively empathize with the Chilean mother and son from that perspective. She does so, however, in markedly more concrete terms than Rich, going so far as to envision the precise way she would kill both herself and her son if confronted with the same situation. The sharp, percussive tap and hiss of consonance in these lines ("slitting his throat, slitting my own throat / to save us that.") underscores the sharp, violent nature of the act described; all those breathy th's evoking the aural quality of a hushed, urgent whisper.

Musicality aside, the language of the poem itself sets up a conceit which Olds develops further in following lines:

...Things that are worse than death:

this new idea enters my life.

The guard enters my life, the sewage of his body, "as they like to do." (13)

In this way, knowledge of human suffering ("this new idea") can be understood as a violent intrusion upon the poet, a kind of rape that "enters" her life and forcefully changes the way she thinks about suffering and death.

In the next three sentences, Olds attempts to assimilate this painful knowledge by means of imagining the Chilean mother and son watching one another's torture, and connecting that imaginary scene to a memory from her childhood.

...The eyes of the five-year-old boy, Dago, watching them with his mother. The eyes of his mother watching them with Dago. And in my living room as a child, the word, Dago. (13)

"Those who suffer have neither a name nor a voice," writes Des Pres. "A condition that makes their lives easy to ignore and dispose of, and reminds us that worldly power controls people by controlling names" (366). By naming the Chilean boy Dago, Olds particularizes him, makes him less "easy to ignore." The name Dago also emerges as an aural mnemonic for Olds that calls up a memory of overheard bigotry from her own upbringing.

Then, as if anticipating the reader's objection to her easy association, she writes, "And nothing I experienced was worse than death" (13). Unlike Rich, Olds is quick to "quantify suffering," making it clear that whatever suffering she experienced as a child in that living room at the hands of those who'd utter racial slurs is not on par with the suffering of the Chilean mother and child.

"There is sometimes a tendency, I think, in some of us," Olds once said in an interview. "To use with some lightness, or lack of gravity or proportion, another person's absolute heaviness." (Excerpt) In the final lines of "Things That Are Worse Than Death," Olds' diction reflects the gravity with which she considers the suffering of Dago and his mother, using language with religious overtones - "bow in welcome, / gracious and eternal death." In this way, Olds achieves what Valis calls "a narrative form of sacrament, a body sacrament, in which the body is revealed in its sacred beauty and worth" (118). 
And thus, without pity, guilt or self-judgment—but rather, with a "force of emotion...that binds the imagination...into a narrative form" (Valis 118)—Olds communicates in the final lines a radical shift in how she's come to think of death:

life was beautiful as our blood on the stone floor to save us that - my son's eyes on me, my eyes on my son-the ram-boar on our bodies making us look at our old enemy and bow in welcome, gracious and eternal death who permits departure. (13)

"There seems to be a point of contact," Valis writes. "Where torture and imagination come together, where what is produced is a revelation that is a kind of monstrous beauty, a confession of a painful turning inside out of our very skin" (119). The monstrously beautiful revelation for Olds, in the case of this poem, is that in extreme circumstances, death can be personified as a merciful rescuer, swooping in to "permit departure" from unbearable pain. Similar to Rich in "Hunger," Olds locates value, at last, in her connection to her son-their eyes locked on one another, intimate even as their blood spills, slipping away from suffering together into the lasting respite of death.

Carolyn Forché groups together the first eight poems of her collection The Country Between Us under the subheading, "In Salvador, 1978-80." During the two years indicated in the subheading, Forché took numerous trips to El Salvador as a journalist and human rights advocate (Valis 123). Within El Salvador at that time, "mayhem prevailed. More than 30,000 politically motivated killings took place between October 1979 and December 1981 alone" (Valis 121). As Noël Valis notes in his essay, "Fear and Torment in El Salvador," Salvadoran authors themselves acknowledged the depths of chaos that their country had plunged into, as shown in the opening lines of a novel by Salvadoran Mario Bencastro: "These days the mere fact of waking up in the morning is cause for real surprise. Death no longer surprises anyone" (122).

The poems that comprise "In Salvador" are among Forché's most wellknown - and most contentious. Her poem "The Colonel" has inspired many responses - from praise, to harsh criticism, even to a dramatization in the film Salvador by Oliver Stone. Critics like Ken Smith, on the one hand, would likely assert - as he did of Joan Didion's essay collection Salvador - that the emotion underpinning Forché's poetry is "untrustworthy," since she produces "a powerful emotional response while masking the distance caused by her ahistorical methods" (qtd. in Valis 129). On the other hand, Valis claims her poem "The Colonel" "suggests how to listen to what cannot be said, how to listen to those who cannot speak" (125).

For the purposes of this essay, I'm most interested in "Return," a fourpage poem from "In Salvador." Like Old's "Things That Are Worse Than Death," Forché's poem is structured such that it implies a dialogue with someone other than the poet, designated alternately as "Josephine" and "you." It begins,

Upon my return to America, Josephine:

the iced drinks and paper umbrellas, clean 
toilets and Los Angeles palm trees moving

like lean women, I was afraid more than

I had been, even of motels so much so

that for months every tire blow-out

was final, every strange car near the house

kept watch and I strained even to remember

things impossible to forget. You took

my stories apart for hours, sitting

on your sofa with your legs under you

and fifty years in your face. (17)

Immediately, Forché invokes the confessional mode, disclosing her "apparently literal" - as Olds would have it (Excerpt) - fear, distress, and paranoia upon returning to the U.S. from El Salvador. Her feelings of panic are so pervasive that even the palm trees, to her, appear as "lean women," evoking starved bodies, an image she will return to throughout the poem. The long opening sentence, with its enjambed lines and infrequent punctuation, lends the confession a rushed feeling, a sense of urgency. Forché also implies a setting — her sofa — and establishes the basic frame for the story by introducing the character Josephine (the poem is dedicated to Josephine Crum). Forché describes Josephine's patience-“"You took/ my stories apart for hours"-and elder-hood—-"fifty years in your face." Throughout the poem, Forché will oscillate between her own voice and the voice of this elder, implying a dialogue between them.

The next 49 lines of the poem are given over to Josephine's reply. Her cool, utterly unsentimental voice tempers the febrile, self-pitying tone of the introductory lines; Josephine's attitude towards Forché is unsympathetic, harsh in its perception of her flaws, naïveté, and self-serving motivations. "As for the cars," she says. "Of course / they watch you and for this don't / flatter yourself" (18). In these lines, she points a finger directly at the vanity hiding beneath Forché's attested paranoia. Likewise, she lances Forché's naïve optimism: "Such things as water pumps / and co-op farms are of little importance / and take years" (18). In this same section, Josephine exposes the exploitative impulses running beneath much of Forché's struggle:

\section{Go try on}

Americans your long, dull story

of corruption, but better to give them what they want. (18)

She continues with a list of sensationally vulgar images - the sort of thing "Americans want" from a foreign conflict zone- "Tell them about the razor, the live wire, / dry ice and concrete, grey rats and above all / who fucked her, how many times and when" (18). This section works on a few different levels. In some ways, it can be read in a forgiving light, exposing the pressure to sensationalize that American social culture puts upon writers like Forché, the hunger of the market for images of "Jose lying/ on the flat bed truck, waving his stumps / in your face" (18). However, the fact of the social pressure itself doesn't exonerate Forché—who, after all, is only being confronted by a literary device. 
"Josephine" - however inspired or based upon a real person - did not write the poem. Forché did, and by including these sensational images - even in the context of a sideways critique of the pressures that pushed her to it - she is still guilty of sensationalizing them on the page, of "giving in to the fascination that horror of this kind holds for us" (Valis 126).

And yet — on an even more removed metaphysical level-what of our response as readers? By self-consciously pointing out the sensational nature of these images, the voice of "Josephine" - and, by extension, Forché herself-also points a finger at us, the readers, implicating our own fascination with the horror she presents. Are we not, in this instance, among Sylvia Plath's voyeuristic "peanut-crunching crowd?" (Plath 15) It's as if, as Deborah Sosin notes in her recent essay, "The Self as Anti-Hero," "[the author] demonstrates throughout [her work] an incisive awareness of [her] flawed individual psychology in the context of our flawed contemporary culture, thus impugning [herself] along with the rest of us" (37).

Another kind of reading of this section of the poem, however, might turn its attention to the story of "Jose," first cut into pieces and buried before "his friends found / the soldiers and made them dig him up / and ask forgiveness of the corpse, once / it was assembled again on the ground." The 49-line section ends with the sentence, "We are / all assembled" (18). In writing on Forché's poem "The Colonel," Valis notes, "if Forché's poem is about dismemberment on one level, it is also about resurrection on another, making whole again" (125). Forché suggests, with this line, that the violence in El Salvador - witnessing it, at leastdismembered her in a figurative sense, psychologically and emotionally. This turn indicates a question that the latter half of the poem will attempt to unravel: how does one re-member oneself after such a shocking dismemberment of the psyche?

In his reading of Rich's poem "Nightbreak," which speaks on Vietnam, Des Pres posits that "the horror has reached such a pitch that the poet, so to say, is cracking up...the theme of the poem is the shattering impact of political intrusion on a self that feels shockingly continuous with the suffering...in a distant place" (364). Evidence of Forché's "cracking up" litters the penultimate section of the poem, in which her voice returns in reply to Josephine's. She claims "I have not rested," "I go mad," "I cannot keep going" (19). She indicates her inability to connect with American men- "their constant Scotch and fine white / hands, many hours of business"-linking, in this way, the idea of "American business" with the "madness" she experiences "in the Safeway, at the many heads / of lettuce... and coffee, especially coffee" (19). Like the palm trees in the opening lines of the poem, "heads of lettuce" evokes the dismembered human body, in large part due to Forché's choice to break the line after the word, "heads." The primary work these lines do, however, is to point out American economic complicity with El Salvador's brutal regime, "reminding us of the larger, devastating role the U.S. played in determining El Salvador's fate...[the] intertwined relationship between two cultures of the Americas" (Valis 117). "Coffee," after all, is a Salvadoran product in high demand in the U.S. By referencing the United States's business interests in El Salvador, Forché again implicates both herself and the reader in the state-sanctioned violence perpetrated 
there by a U.S.-backed regime. As Said notes (speaking specifically of the Middle Eastern oil industry but analogous [if, admittedly, not equivalent] to the market system in El Salvador),

No one needs to be reminded that oil, the region's greatest resource, has been totally absorbed into the United States economy. By that I mean not only that the great oil companies are controlled by the American economic system; I mean also that Arab oil revenues, to say nothing of marketing, research, and industry management, are based in the United States... My point is that the relationship is a one-sided one, with the United States a selective customer of a very few products (oil and cheap manpower, mainly), the Arabs highly diversified consumers of a vast range of United States products, material and ideological. (324)

The consequence of such a "one-sided relationship" - that the U.S. and its citizens have a direct financial interest in maintaining the current brutal leadership in El Salvador, due to its U.S. sympathies - troubles Forché to the point of madness.

Critics, however, might take issue here with Forché's easy condemnation of U.S. foreign policy, the figurative line she draws between the "heads of lettuce" and the severed heads of Salvadorans, noting that she offers "no trenchant political analysis and suggests no active political response to the readers" (Valis 121). According to Valis, however, "these critics miss the point" (121). Forché is not a political analyst. She is not a historian. She is a poet, one among the likes of those described by Levertov, "driven to maintain a dialogue with [herself]," striving to avoid "opinionated rhetoric," to do what Said urges scholars to in the final words of his book: "identify with human experience" (328).

Towards the end of the poem's penultimate section, Forché recalls a story of the "American attaché" in El Salvador, in particular remembering the unhappy wife of a diplomat who, in her "drunken kindness," ...flew her own plane, stalling out

after four martinis to taxi on an empty

field in the campo and to those men and women announce she was there to help. (19)

The dark, ironic humor of the story indicates Forché's disgust of the woman's quintessentially American brand of altruistic escapism and stupidity. Curiously, Forché excludes herself from this impulse, standing at a judgmental distance that, were it not called out so harshly by Josephine in the final lines of the poem, might read as snark.

Josephine, however, challenges Forché's self-pity and sense of helplessness, her posture of remove from escapist motivations. In her final reply, she sets up this harsh confrontation with yet another list of disturbing images"so... you've learned a little /about starvation: a child like a supper scrap / filling with worms," "reports / of mice introduced into women, of men / whose testicles are crushed like eggs," "where the naked are tied open / and left to the hands of those who erase / what they touch." Here, like in her first reply, Josephine says, "We are all erased / by them" (20). Unlike Forché, who does not seem to consider 
herself among the ranks of the greedy American businessmen and stupid drunk diplomats, Josephine draws a compassionate circle around them all, saying, "[we] no longer resemble decent / men. We no longer have the hearts, / the strength, the lives of women" (20). It is a merciful take, one that hearkens back to Rich's vision of the "tribal union" conferred upon all those victimized by crimes against humanity. Unlike Rich, however, in this vision, even men are included, victimized alongside women by the reality of torture in El Salvador.

It's from this place of merciful compassion that the poem turns, at last, to its final searing critique of Forché herself:

Your problem is not your life as it is

in America, not that your hands, as you

tell me, are tied to do something. It is

that you were born to an island of greed

and grace where you have this sense

of yourself as apart from others. It is

not your right to feel powerless. Better

people than you were powerless.

You have not returned to your country,

but to a life you never left. (20)

"Josephine" excoriates Forché's false sense of helplessness, making the crucial distinction that her psychic suffering is not, in fact, sourced from true

powerlessness, but rather a "feeling" of powerlessness. She challenges her grandiosity and narcissism - "better people than you were powerless." The final lines indicate, at last, an escapist motivation for engaging with the Salvadoran conflict in the first place, suggesting that Forché's life was exactly as fragmented, unlivable and unhappy before she left - thus implying, by extension, that what's really changed for Forché is her perception of and feelings about reality, not reality itself. "You've learned a little," Josephine says over and over again throughout the poem. "You know," "you've seen," "you've heard"- the repetition of these phrases work to emphasize that the essential psychic shift within Forché concerns the end of her own ignorance.

How exactly Forché - and, by extension, any American awake to the suffering in El Salvador or elsewhere - is to re-member herself, however; that complex issue is most directly addressed by Josephine's articulation of "the problem:" "you were born to an island of greed / and grace where you have this sense / of yourself as apart from others." Like both Rich and Olds, Forché locates, in these lines, a powerful value in connection to one another. "The problem" with Americans, she suggests, is not only our greed, but also our isolation, our illusion of autonomy ("island," "sense of yourself as apart from others"). If we are to "assemble" ourselves, in the light of everything violent and atrocious effected as a result of our nation's greed and loneliness, Forché seems to suggest that we begin doing so by pulling our dismembered society back together, and once we are all "assembled again on the ground / like a man," collectively witness the violent reality of what we've done. Only then, perhaps, may we "ask forgiveness of the corpse." 
In the closing of his groundbreaking work Orientalism, Said notes that, were it not for the existence of a false, post-colonial set of oppressive ideas about the "Oriental Other," "there would be scholars, critics, intellectuals, human beings, for whom the racial, ethnic, and national distinctions were less important than the common enterprise of promoting human community" (328).

The three poets I've examined, while each speaking to human suffering in a different part of the world, are united in pursuit of this common enterprise. At the heart of each poem, the poet's embedded an ideological message that transcends the particular contours of the specific conflict about which they speak; that is, that a collective reaching towards "human community" constitutes the most powerfully redemptive response to grave human suffering. Each in their own distinctive voices, these poets urge us to "find each other," to put our eyes on our children, to question our "sense of [ourselves] as apart from others." In this moment, perhaps more than ever in our country - a moment of tremendous xenophobia, a moment where campaigning politicians compare Syrian refugees to dogs (Dann), a moment when "political and historical circumstances have made an emotion like sympathy appear as irrelevant" - these poems are all the more crucial, as the poets who wrote them "pursue with dogged persistence this peculiar sense of the sacred embodied in human worth, in the midst of degradation and torment" (Valis 129).

Note

1. For the purposes of this essay, I defer to Said's definition of the Third World as he gives it in Orientalism, which includes "China, Indochina, the Near East, Africa, and Latin America" (46).

\section{Works Cited}

Dann, Carrie. "Carson Likens Worry About Syrian Refugees to Fear of 'Mad Dogs." NBC News. NBC News, 19 Nov. 2015. Google Search. Web. 2 Dec. 2015.

Des Pres, Terrence. "Adrienne Rich, North America East." Adrienne Rich's Poetry and Prose. Ed. Gelpi, Barbara Charlesworth and Albert Gelpi. New York: W. W. Norton \& Company, 1993. 357-369. Print.

"An Excerpt from an Interview with Olds." Department of English at $U$ of Illinois. Department of English at U of Illinois, n.d. Web. 2 Dec. 2015. <http://www.english.illinois.edu/maps/poets/m_r/olds/excerpt.htm >

Forché, Carolyn. The Country Between Us. New York: Harper \& Row, 1981. Print.

Hitchcock, Peter. "Postcolonial Africa? Problems of Theory." Women's Studies Quarterly 25.3/4 (1997) : 233-244. JSTOR. Web. 29 Nov. 2015.

Levertov, Denise. The Poet in the World. New York: New Directions Books, 1960. Print. 
Olds, Sharon. The Dead and the Living. New York: Alfred A. Knopf, 1983. Print. Plath, Sylvia. Ariel: The Restored Edition. New York: Harper Perennial, 2004.

Print.

Rich, Adrienne. The Dream of a Common Language. New York: W. W. Norton \& Company, 2013. Print

--. What Is Found There: Notebooks on Poetry and Politics. New York: W. W. Norton \& Company, 2003. Print.

Said, Edward W. Orientalism. New York: Pantheon Books, 1978. Print.

Sosin, Deborah. "The Self as Antihero: In the Essays of Nora Ephron, David

Sedaris, and Steve Almond." The Writer's Chronicle Oct./Nov. 2015: 2937. Print.

Valis, Noël. "Fear and Torment in El Salvador." The Massachusetts Review 48.1 (2007): 117-131. JSTOR. Web. 29 Nov. 2015. 